\title{
Traceability of Animal Meals in Japanese Quail Eggs Using the Technique of 13C E 15N* Stable Isotopes
}

-Author(s)
Mori C1
Ducatti C ${ }^{2}$
Pizzolante $C^{3}$
Kakimoto SK
Denadai JC
1 Professor at UNESP - Registro Experimental
Campus
2 Professor of the Department of Physics and
Biophysics/IBB/UNESP/Botucatu
3 Researcher of Agência Paulista de
Tecnologia dos Agronegócios/Brotas
4 DVM - Granjas Kakimoto
5 Ph. D. student at the Department of Animal
Science /FMVZ/UNESP/Botucatu
* Post-doctorate grant given by Fundação de
Amparo a Pesquisa do Estado de São Paulo
Process n. 2007/O6707-8

\section{Mail Adress}

Corresponding author e-mail address Cleusa Mori

Rodovia Br 116 Km 460 - Caixa Postal 122 CEP: 11900-000 Registro, São Paulo cleusamori@uol.com.br

\section{Keywords}

Carbon-13, Coturnix coturnix japonica, bovine meat and bone meal, certification, nitrogen-15.

\section{ABSTRACT}

The objective of this study was to trace the inclusion of bovine meat and bone meal (BMBM) in the diet of Japanese quails by analyzing eggs and egg fractions (yolk and albumen) by the technique of carbon-13 $\left({ }^{13} \mathrm{C}\right)$ and nitrogen-15 $\left({ }^{15} \mathrm{~N}\right)$ stable isotopes. In the trial, 120 Japanese quails were distributed in six treatments with four replicates of five birds each. The following treatments were applied: feed based on corn and soybean meal, containing graded BMBM inclusions $(0,1,2,3,4$ or $5 \%$ ). After 42 days, 20 eggs per treatment were randomly collected for three consecutive days. Ten eggs were used for yolk and albumen sample collection, and ten for total egg sample collection. It was possible to detect the dietary inclusion of $1 \%$ BMBM in the egg and its fractions. Therefore, the technique of isotopes ${ }^{13} \mathrm{C}$ and ${ }^{15} \mathrm{~N}$ is able of tracing since $1 \%$ inclusion level of BMBM in the diet of Japanese quails in eggs and their fractions.

\section{INTRODUCTION}

The increasing demands for food quality and safety has forced farmers and agribusinesses to change their production systems in order supply to their customers products that are reliably and provenly safe.

Global food incidents, such as BSE (Bovine Spongiform Encefalopathy) or "mad cow disease", dioxin contamination, allergens, genetically modified organisms, pesticide and heavy metal contamination, and avian fly have scared consumers, who now demand safe food supply.

During the last decades, the stable isotope technique has been increasingly applied in agricultural, ecological, and physiological research, and has shown to be a reliable method to study processes related to nutrient digestion, absorption, and metabolism in humans and animals, as well as to identify the origin and quality of animal and vegetable products (González-Martin et al. 2001; Gonzáles-Martin et al., 1999; Piasentier et al., 2003).

Denadai et al. (2005), using the double isotope axis $\left(\delta^{13} C\right.$ and $\left.\delta^{15} \mathrm{~N}\right)$, analyzed eggs produced in two farms of the region of Bastos, São Paulo, Brazil. One of the farmers informed that layers were fed only vegetable feedstuffs, whereas the other, said animal ingredients were used. The authors indeed found different isotope patterns, and suggested the possibility of tracing the inclusion of animal meals in layer diets in the final product (eggs).

Therefore, methodologies that detect animal by-products in the diet of Japanese quail layers analyzing their eggs should ensure reliable information on this product, as well as allow certification of origin by governmental regulation agencies. This would ensure the safety of Japanese quail eggs, which consumption has significantly increased in the last few years, particularly when consumed as preserved eggs. 
Japanese quails are an important sector of the Brazilian poultry industry, as shown by its accelerated growth during the last few years. According to IBGE data (2010), the inventory of Japanese quails housed in Brazil between 2005 and 2010 doubled, going from 6.8 million to 13 million birds, representing an increase of approximately $90 \%$, which is very significant when compared with the $12.96 \%$ increase in the numbers of layer chickens during the same period. Egg production increased from $117,638,000$ to $232,398,000$ dozen or $97.55 \%$.

The objective of this study was to trace the inclusion of bovine meat and bone meal (BMBM) in the diet of Japanese quails by analyzing eggs and egg fractions (yolk and albumen) by the technique of carbon-13 $\left({ }^{13} \mathrm{C}\right)$ and nitrogen-15 $\left({ }^{15} \mathrm{~N}\right)$ stable isotopes.

\section{MATERIALS AND METHODS}

The field experiment was carried out at the facilities of the Research and Development Unit of Brotas of the Agribusiness Technology Agency (Agência Paulista de
Tecnologia dos Agronegócios - APTA) of the Agriculture Department of the State of São Paulo. Feeds and eggs were analyzed at the Center of Environmental Stable Isotope Center of the Biosciences Center of UNESP, Botucatu campus. In this trial, 120 Japanese quail females were reared under the same management conditions, with feed and water offered ad libitum. Birds were housed in a $3.0 \mathrm{~m}$ wide and $12.0 \mathrm{~m}$ long barn made of bricks, with open sides with $0.50 \mathrm{~m}$ high walls and $1.50 \mathrm{~m}$ high wire mesh, side curtains, and clay-tile roof. Birds were distributed in $24100 \mathrm{~cm}$ long, $34 \mathrm{~cm}$ deep, and 16-cm high cages divided in four 25 $\mathrm{cm}$ internal compartments that housed five birds each, totaling 20 birds per cage $\left(170 \mathrm{~cm}^{2}\right.$ per bird). Each cage compartment was equipped with a nipple drinker and a trough feeder placed in front of the cage. Natural and artificial light were provided 16 hours per day at an intensity of 22 lumen $\mathrm{m}^{-2}$, and timer was used to control the light period during the entire experimental period. Maximal and minimal temperatures were daily recorded using a thermometer placed at the center of the barn. A completely randomized experimental

Table 1 - Feedstuff composition, calculated nutritional levels, and mean isotope values of the experimental diets.

\begin{tabular}{|c|c|c|c|c|c|c|}
\hline \multirow{2}{*}{ Ingredients (\%) } & \multicolumn{6}{|c|}{ Experimental diets } \\
\hline & TO & $\mathrm{T} 1$ & $\mathrm{~T} 2$ & T3 & T4 & T5 \\
\hline Ground corn & 52.45 & 53.01 & 53.60 & 54.14 & 54.74 & 55.33 \\
\hline Soybean meal & 36.10 & 35.11 & 34.12 & 33.13 & 32.12 & 31.11 \\
\hline Bovine meat and bone meal & 0.00 & 1.00 & 2.00 & 3.00 & 4.00 & 5.00 \\
\hline Soybean oil & 1.45 & 1.30 & 1.13 & 0.99 & 0.82 & 0.65 \\
\hline Calcitic limestone & 7.05 & 6.96 & 6.86 & 6.72 & 6.61 & 6.53 \\
\hline Dicalcium phosphate & 2.00 & 1.67 & 1.34 & 1.07 & 0.76 & 0.43 \\
\hline Salt & 0.35 & 0.35 & 0.35 & 0.35 & 0.35 & 0.35 \\
\hline Mineral and vitamin supplement ${ }^{1}$ & 0.60 & 0.60 & 0.60 & 0.60 & 0.60 & 0.60 \\
\hline TOTAL & 100 & 100 & 100 & 100 & 100 & 100 \\
\hline \multicolumn{7}{|l|}{ Calculated nutritional levels } \\
\hline Metabolizable energy (kcal/kg) & 2.750 & 2.750 & 2.750 & 2.750 & 2.750 & 2.750 \\
\hline Crude protein (\%) & 21.00 & 21.00 & 21.00 & 21.00 & 21.00 & 21.00 \\
\hline Crude fiber (\%) & 3.27 & 3.23 & 3.19 & 3.15 & 3.11 & 3.07 \\
\hline Calcium (\%) & 3.20 & 3.20 & 3.20 & 3.20 & 3.20 & 3.20 \\
\hline Available phosphorus (\%) & 0.46 & 0.46 & 0.46 & 0.46 & 0.46 & 0.46 \\
\hline Methionine (\%) & 0.45 & 0.45 & 0.45 & 0.45 & 0.45 & 0.45 \\
\hline Methionine + cystine (\%) & 0.80 & 0.79 & 0.79 & 0.78 & 0.78 & 0.79 \\
\hline Lysine (\%) & 1.16 & 1.15 & 1.14 & 1.13 & 1.12 & 1.11 \\
\hline \multicolumn{7}{|l|}{ Mean isotope values } \\
\hline$\delta^{13} C^{3}(\% 0)$ & -17.98 & -17.45 & -17.40 & -17.03 & -16.91 & -16.79 \\
\hline$\delta^{15} \mathrm{~N}(\% 0)$ & 1.32 & 1.63 & 1.66 & 1.82 & 1.96 & 2.33 \\
\hline
\end{tabular}

${ }^{1}$ Composition of the vitamin and mineral supplement (multimix ${ }^{\circledast}$ )/ $\mathrm{kg}$ feed: pantothenic acid 5,000 mg; choline 43,400 mg; niacin 6,680,000 mg; Vit. A 1,666,666.7 IU; Vit. B1 500,700 mg; Vit. B12 1,680,000 mcg; Vit B2 1,000 mg; Vit. B6 583,300 mg; Vit. D3 333,333,300 IU; Vit. E 1,333,300 mg; Vit. K3 333,300 mg; Cu 1,333,300 mg; Fe 8,333,300 mg; I 200,000 mg; Mn 11,666,600 mg; Zn 8,333,300 mg; Se 33,330mg, growth promoter 1,166,670 mg, antioxidant 16,680,000 mg, vehicle q.s.p. 1,000,000 g.

${ }^{3}$ Mean isotope values expressed as $\delta^{13} \mathrm{C}$ and relative to Peedee Belemnite (PDB) standard and atmospheric air as standard for $\delta^{15} \mathrm{~N}$. 
design was applied, with six treatments with four replicates each. Each cage, which four divisions contained five birds each, was considered one replicate. The following treatments were applied: T0 - control feed based on corn and soybean meal with no inclusion of bovine meat and bone meal (BMBM); T1 - 1\% BMBM inclusion; T2 - 2\% BMBM inclusion; T3 - 3\% BMBM inclusion; T4 - 4\% BMBM inclusion; and $\mathrm{T} 5-5 \%$ BMBM inclusion.

Protein, calcium, phosphorus, metabolizable energy, and amino acid levels of the feedstuffs used in the experimental diets were estimated according to Rostagno et al. (2005). The chemical analysis showed that the used BMBM contained $93.75 \%$ dry matter (DM), 45.75\% crude protein (CP), 8.43\% ether extract $(\mathrm{EE})$, and $48.17 \%$ ash content (A).

The experimental diets (Table 1) were formulated to supply birds' nutritional requirements, as established by Rostagno et al. (2005), and to contain equal energy, protein, calcium, phosphorus, methionine+cystine, and lysine levels.

After egg production peak, birds were fed the experimental diets for 42 days (Table 1) in order to replace carbon and nitrogen in the tissues for those present in the experimental diets.

After 42 days of the beginning of the experiment, 20 eggs per treatment were randomly collected for three consecutive days. Ten eggs were used for yolk and albumen sample collection, and ten for total egg sample collection.

Yolk and albumen were separated and placed in duly identified plastic bags, whereas entire eggs (yolk + albumen) were homogenized in a food processor and also placed in duly identified plastic bags. Samples were then frozen at $-20^{\circ} \mathrm{C}$ until processing. At processing, samples were thawed and dried in a forced-ventilation oven (Marconi - model MA 035) at $56^{\circ} \mathrm{C}$ for $24 \mathrm{~h}$ (albumen) and for $48 \mathrm{~h}$ (egg and yolk). Dried samples were then frozen in a cryogenic mill (Spex-model 6750 freezer/mill) at $-190^{\circ} \mathrm{C}$. Freeze-milling of the samples were carried out in two steps: pre-freezing for one minute and then freezing and grinding to powder for $5 \mathrm{~min}$. This procedure allowed obtaining particle sizes smaller than $60 \mu \mathrm{m}$ (Rosa et al., 2002).

After grinding, egg (yolk + albumen) and yolk samples were de-fatted in ethylic ether in a Soxhlet apparatus for $4 \mathrm{~h}$, and ground again to obtain a homogenous mixture. This extraction is necessary, according to Tieszen et al. (1983), because lipid-rich fractions are poorer in ${ }^{13} \mathrm{C}$ relative to those with lower lipid content.
Analyses were conducted at the Stable Isotopes Center of the Biosciences Institute of UNESP, Botucatu campus, SP, Brazil. Samples were weighed and approximately 50-60 $\mu \mathrm{g}$ and 500-600 $\mu \mathrm{g}$ were placed in tin capsules to determine carbon and nitrogen isotope ratios, respectively. For feed analysis, volumes of 60-70 $\mu \mathrm{g}$ and 1600-1700 $\mu \mathrm{g}$ were used, respectively.

Capsules were introduced using an automatic sampler in the element analyzer (EA 1108 - CHN Fisons Instruments, Rodano, Italy), in which samples were burnt, producing $\mathrm{CO}_{2}$ and $\mathrm{N}_{2}$. These gases were separated in gas chromatography column and analyzed in an isotope ratio mass spectrometer (Delta $\mathrm{S}$ - Finnigan MAT, Bremen, Germany).

Sample isotope composition was determined using a mass spectrometer (DELTA-S, Finnigan Mat) coupled to an element analyzer (EA 1108 CHN).

Isotope ratio values were expressed as delta per thousand relative to PeeDee Belemnite (PDB) international standards for ${ }^{13} \mathrm{C}$, and atmospheric air nitrogen for ${ }^{15} \mathrm{~N}$, according to the following general equation:

$$
\delta X_{\text {(sample, standard) }}=\left[\left(\mathrm{R}_{\text {sample }} / \mathrm{R}_{\text {standard }}\right)-1\right] \times 10^{-3}
$$

Where: $\mathrm{R}$ represents the ratio between the least and the most abundant isotope, in particular ${ }^{13} \mathrm{C} /{ }^{12} \mathrm{C}$ and ${ }^{15} \mathrm{~N} /{ }^{14} \mathrm{~N}$. Adimensional.

The obtained isotope results were submitted to multivariate analysis of variance (MANOVA) with the aid of the GLM procedure (General Linear Model) of the statistical program SAS (1999).

Data were generated by the error matrix of each tissue, and then graphically distributed into regions (ellipses) at 95\% confidence level to detect possible isotope pair differences as a function of experimental treatments. In order to be different from the control treatment, the confidence region of a determined treatment (ellipse) cannot overlap any of the graph axes (control treatment). When an ellipse overlaps one of the axes, the difference between ${ }^{13} \mathrm{C}$ and ${ }^{15} \mathrm{~N}$ treatment means is equal to zero, and therefore, there are no differences among the evaluated treatments.

\section{RESULTS AND DISCUSSION}

Table 2 shows that ${ }^{13} \mathrm{C}$ isotope values increased as the percentage of meat and bone meal (BMBM) dietary inclusion increased. This was probably due to the variations in the percentage composition of the dietary ingredients. As diets were formulated to 
contain equal energy and protein levels, when BMBM inclusion increased, soybean meal and soybean oil levels were reduced and corn inclusion increased. This ${ }^{13} \mathrm{C}$ and ${ }^{15} \mathrm{~N}$ isotope enrichment is consistent with the findings of Oliveira et al. (2010), Carrijo et al. (2006), Gottmann (2007), Mori et al. (2007, 2008) e Denadai et al. (2008), who used animal meal in poultry diets (broilers, meat-type Japanese quails, and commercial layers).

Table 2 - Mean $\delta^{13} \mathrm{C}$ and $\delta^{15} \mathrm{~N}$ isotope values and their respective standard deviations $(n=2)$ determined in the feedstuffs of the experimental diets.

\begin{tabular}{lcc}
\hline Ingredients & $\mathrm{d} 13 \mathrm{C}(\% 0)$ & $\mathrm{d} 15 \mathrm{~N}(\% 0)$ \\
\hline Meat meal - 40 & $-11.73 \pm 0.10$ & $7.66 \pm 0.02$ \\
\hline Ground corn & $-13.92 \pm 0.18$ & $4.07 \pm 0.08$ \\
\hline Soybean meal 45 & $-26.29 \pm 0.04$ & $0.43 \pm 0.05$ \\
\hline Soapstock & $-32.00 \pm 0.11$ & - \\
\hline
\end{tabular}

According to Vogel (1993), carbon-13 dietary enrichment may be due to the isotope enrichment of $\mathrm{C} 4$ plants relative to $\mathrm{C} 3$ plants, which $\delta^{13} \mathrm{C}$ vary between $-9 \%$ and $-16 \%$ and $-22 \%$ and $-34 \%$, respectively, considering plant species and analyzed part. DeNiro
\& Esptein (1978) observed the animal meals used as feedstuffs reflect the isotope signal of the animal from which they derive, and it is around $2 \%$ for $\delta^{13} \mathrm{C}$.

The $\delta^{15} \mathrm{~N}$ to ${ }^{14} \mathrm{~N}$ ratio in plants changes according to how plants fix nitrogen. Soybeans have a $\delta^{15} \mathrm{~N}$ value around one unit, which is close to the standard $\mathrm{N}_{2}\left(\delta^{15} \mathrm{~N}=0.0 \pm 1.0 \%\right.$ ) because it fixes nitrogen from the air (Handley \& Raven, 1992; Werner \& Schimidt, 2002). Plants that cannot fix atmospheric $N_{2}$ depend mostly on nitrogen soil content, which may present significant differences as a function of fertilization (Choi et al. 2002). When nitrogen is absorbed from organic matter, $\delta^{15} \mathrm{~N}$ is higher, around $5 \%$. Negative $\delta^{15} \mathrm{~N}$ values are observed in dry and sandy soils, which organic matter content is very low. When manure is added as natural soil fertilizer, isotope fractioning is high, with $\delta^{15} \mathrm{~N}$ around $10 \%$ (Shibuya et al., 2006).

Moreover, isotope values of animal meals used as feedstuffs reflect the isotope signal of the animal from which they derive, and are around $2 \%$ for $\delta^{13} \mathrm{C}$ (Deniro \& Esptein, 1978) and around 3\%o (2-5\%) for $\delta^{15} \mathrm{~N}$, because body nitrogen as a whole is enriched as trophic level increases (Deniro \& Esptein, 1981).

There was an increasing enrichment of $\delta^{13} \mathrm{C}$ and $\delta^{15} \mathrm{~N}$ in eggs and their fractions (Table 3 ), similar to diet enrichment due to the inclusion of increasing BMBM levels. Although each egg fraction belonging to a same treatment presented different isotope signature, the

Table 3 - Mean $\delta^{13} \mathrm{C}$ and $\delta^{15} \mathrm{~N}$ values of the eggs and their fractions $(\mathrm{n}=10)$ of Japanese quail layers fed different dietary meat and bone meal inclusion levels

\begin{tabular}{|c|c|c|c|c|}
\hline Treatments $^{1}$ & & Egg & Yolk & Albumen \\
\hline \multirow{2}{*}{ TO } & $\mathrm{d}^{13} \mathrm{C}(\%)$ & $-20.68 \pm 0.19$ & $-20.64 \pm 0.17$ & $-20.09 \pm 0.26$ \\
\hline & $d^{15} \mathrm{~N}(\% 0)$ & $4.67 \pm 0.07$ & $4.65 \pm 0.05$ & $3.50 \pm 0.10$ \\
\hline \multirow{2}{*}{ T1 } & $d^{13} \mathrm{C}(\%)$ & $-19.95 \pm 0.09$ & $-20.03 \pm 0.04$ & $-19.70 \pm 0.08$ \\
\hline & $d^{15} \mathrm{~N}(\% 0)$ & $4.79 \pm 0.08$ & $4.75 \pm 0.09$ & $3.63 \pm 0.10$ \\
\hline \multirow{2}{*}{$\mathrm{T} 2$} & $d^{13} \mathrm{C}(\%)$ & $-19.76 \pm 0.21$ & $-19.61 \pm 0.25$ & $-19.33 \pm 0.08$ \\
\hline & $d^{15} \mathrm{~N}(\% 0)$ & $4.91 \pm 0.11$ & $4.82 \pm 0.06$ & $3.69 \pm 0.07$ \\
\hline \multirow{2}{*}{ T3 } & $\mathrm{d}^{13} \mathrm{C}(\%)$ & $-19.34 \pm 0.15$ & $-19.31 \pm 0.09$ & $-19.21 \pm 0.09$ \\
\hline & $d^{15} \mathrm{~N}(\%)$ & $5.00 \pm 0.10$ & $4.98 \pm 0.09$ & $3.79 \pm 0.07$ \\
\hline \multirow{2}{*}{ T4 } & $\mathrm{d}^{13} \mathrm{C}(\%)$ & $-18.88 \pm 0.19$ & $-18.83 \pm 0.19$ & $-18.92 \pm 0.15$ \\
\hline & $d^{15} \mathrm{~N}(\%)$ & $5.11 \pm 0.07$ & $5.12 \pm 0.05$ & $3.85 \pm 0.07$ \\
\hline \multirow{2}{*}{ T5 } & $d^{13} \mathrm{C}(\%)$ & $-18.48 \pm 0.17$ & $-18.39 \pm 0.05$ & $-18.27 \pm 0.13$ \\
\hline & $d^{15} \mathrm{~N}(\%)$ & $5.20 \pm 0.10$ & $5.29 \pm 0.10$ & $4.03 \pm 0.10$ \\
\hline
\end{tabular}

'TO: control feed based on corn and soybean meal with no inclusion of bovine meat and bone meal (BMBM); T1: 1\% BMBM inclusion; T2: $2 \%$ BMBM inclusion; T3: 3\% BMBM inclusion; T4: 4\% BMBM inclusion; and T5: 5\% BMBM inclusion. 
obtained values are consistent with those presented by Deniro \& Epstein (1976; 1978; 1981), who said that animals are what they isotopically eat, with $\pm 2 \%$ variation for ${ }^{13} \mathrm{C}$ and $\pm 3 \%$ for ${ }^{15} \mathrm{~N}$.

One week before the beginning of the experiment, egg $(n=12)$ and diet $(n=2)$ samples were collected and isotopically analyzed. Egg presented $\delta^{13} \mathrm{C}=-20.13 \pm$ $0.10 \%$ and $\delta^{15} \mathrm{~N}=4.14 \pm 0.15 \%$, whereas diets showed $\delta^{13} \mathrm{C}=-17.66 \pm 0.18 \%$ and $\delta^{15} \mathrm{~N}=1.10 \pm 0.16 \%$. When the experimental diets started to be fed, these values changed (Table 3), with complete replacement by the isotopes present in the experimental diets. This finding is in agreement with Denadai et al. (2006), who showed that there is complete carbon replacement in egg tissue in 24.5 to 33.6 as experimental diet changes.

In order to be considered different from the control group, the confidence region of any determined treatment cannot overlap any axis of the graph. The fact of the ellipse overlaps one the axes shows that the $\delta^{13} \mathrm{C}$ and $\delta^{15}$ difference between the compared treatments is equal to zero, and therefore, treatments are not different. It was observed that in eggs (yolk + albumen), isotope pair mean for the treatment with $1.0 \%$ BMBM inclusion was different from the control treatment, because the confidence region did not overlap the graph axis where the difference was equal to zero for nitrogen-15 (Figure 1). As BMBM dietary levels increased, the distance of the isotope pairs from the graph axes increased, presenting statistical difference from the treatment consisting of the strictly vegetable diet.

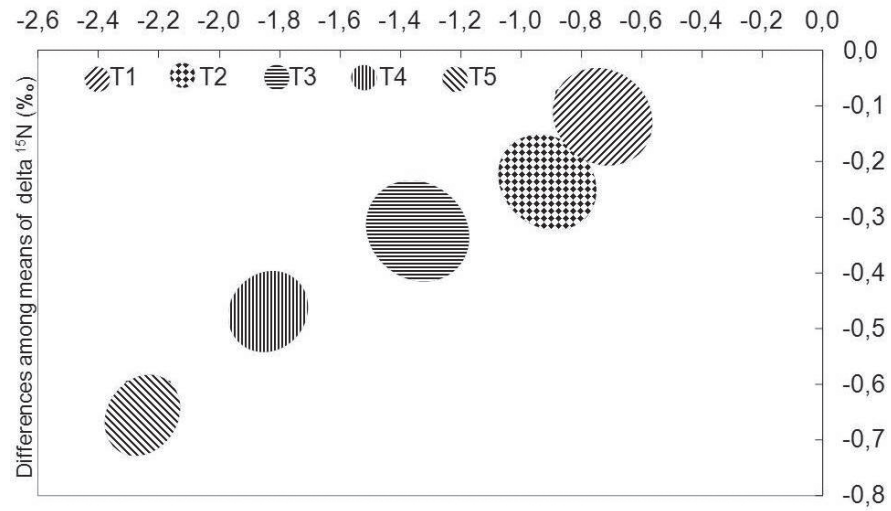

Differences among means of delta ${ }^{13} \mathrm{C}(\% \circ)$

Figure 1. Confidence regions of $\delta^{13} \mathrm{C}$ and $\delta^{15} \mathrm{~N}$ values in the eggs of Japanese quail layers for dietary BMBM inclusion levels of 1, 2, 3, 4 and 5\% (corresponding to T1, T2, $\mathrm{T} 3, \mathrm{~T} 4$, and T5) relative to treatment $\mathrm{TO}$ (graph axis).

The same trend observed for eggs was detected in the yolk fraction (Figure 2), with difference of the $1.0 \%$ BMBM from the strictly vegetable treatment (TO) and the same linear increase in the distance of the confidence ellipses from the axes as animal meal inclusion in the diet increased.

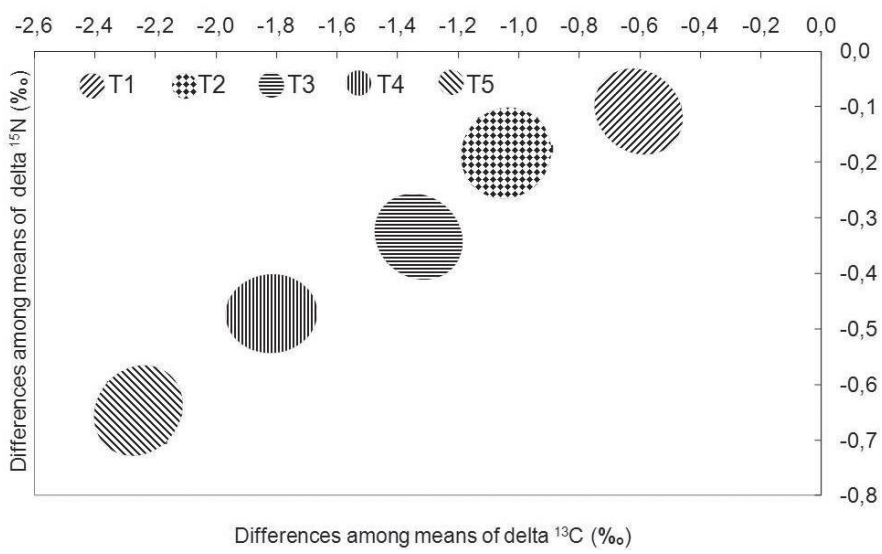

Figure 2. Confidence regions of $\delta^{13} \mathrm{C}$ and $\delta^{15} \mathrm{~N}$ values in the egg yolk of Japanese quail layers for dietary BMBM inclusion levels of 1, 2, 3, 4 and 5\% (corresponding to T1, T2, $\mathrm{T} 3, \mathrm{~T} 4$, and T5) relative to treatment $\mathrm{T0}$ (graph axis).

In the albumen fraction, isotope pair means of the treatment with $1.0 \%$ inclusion BMBM were different from the strictly vegetable treatment (TO) (Figure 3). Although the confidence ellipses presented increasing linearity, these overlapped for the treatment with the dietary inclusion of $2.0 \%$ and $3.0 \%$ BMBM.

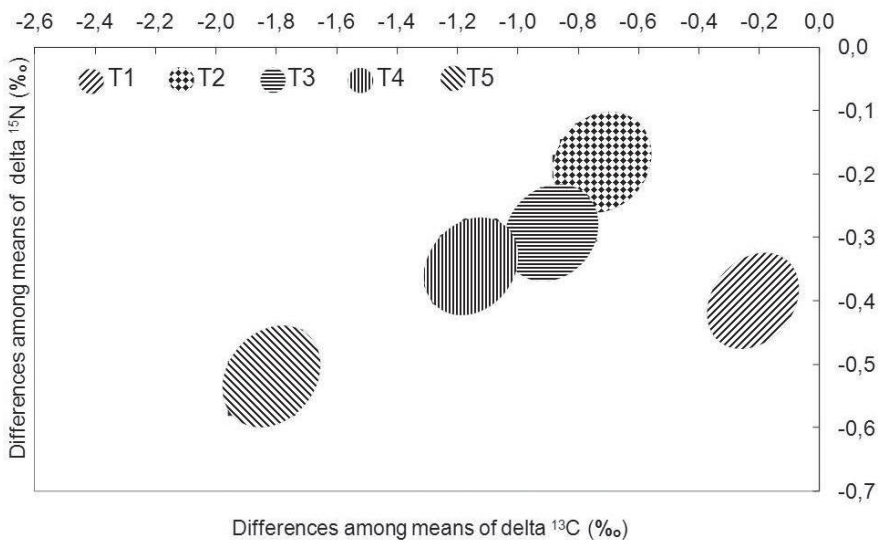

Figure 3. Confidence regions of $\delta^{13} \mathrm{C}$ and $\delta^{15} \mathrm{~N}$ values in the egg albumen of Japanese quail layers for dietary BMBM inclusion levels of 1, 2, 3, 4 and 5\% (corresponding to T1, $\mathrm{T} 2, \mathrm{~T} 3, \mathrm{~T} 4$, and T5) relative to treatment $\mathrm{T0}$ (graph axis).

The variations among fractions are not well understood yet. According to Tiezen et al. (1983), different biochemical fractions are isotopically different, and isotope differences in the body may be a reflex of their different biochemical compositions. Fractions are poorer in lipids would possibly have higher $\delta^{13} \mathrm{C}$ values than those with higher lipid content, being relatively poor in ${ }^{13} \mathrm{C}$. However, in the present study, this was not observed, as the behavior of the entire egg and the yolk fraction was similar to that of the albumen fraction, which lipid content is lower. 
The BMBM detection level in the eggs obtained in the present study was lower than that found by Denadai et al. $(2008,2011)$ in commercial layer chickens. This may have been due to metabolism differences between these two species, as well as between the numbers of replicates between these studies.

The figures above show that any internal egg fraction, i.e., both egg and albumen can be used to detect the inclusion of BMBM in the diet of Japanese quail layers from the level of $1.0 \%$. When birds are fed animal meals since their first day of life, dietary animal meal inclusion can be immediately detected, because quails start lay at 38 days of age. Moreover, it is possible to trace animal meals in Japanese quail feeding also in the albumen, which is faster to process than other egg fractions and meat because it dehydrates faster. For instance, 48 hours are required to dry yolk, whereas 24 hours are necessary when albumen is used. Another advantage is that albumen is poor in fatty acids, reducing the fat-extraction step during sample processing.

\section{CONCLUSION}

Under the conditions of the present experiment, it may be concluded that the technique of ${ }^{13} \mathrm{C}$ and ${ }^{15} \mathrm{~N}$ stable isotopes is capable of tracing the inclusion of $1 \%$ or more of bovine meat and bone meal in the diet of Japanese quail layers by analyzing eggs and their fractions.

\section{REFERENCES}

Carrijo AS, Pezzato AC, Ducatti C, Sartori JR, Trinca L, Silva ET. Traceability of Bovine Meat Bone Meal in Poultry by Stable Isotope Analysis. Revista Brasileira de Ciência Avícola/ Brazilian Journal of Poultry Science 2006;8(1):37-42

Choi WJ, Lee SM, Ro HM, Kim KC, Yoo SH. Natural ${ }^{15} \mathrm{~N}$ abundances of maize and soil amended with urea and composted pig manure. Plant and Soil 2002;245(2):223-232.

Denadai JC, Ducatti C, Sartori JR, Pezzato AC, Gottmann R. Rastreabilidade da farinha de carne e ossos bovinos em ovos de poedeiras comerciais pela técnica dos isótopos estáveis do carbono e nitrogênio. Revista Brasileira de Zootecnia 2011; 40(12):2760-2766.

Denadai JC, Ducatti C, Sartori JR, Pezzato AC, Móri C, Mituo MAO, Bordinhon AM. The traceability of animal meals in layer diets as detected by stable carbon and nitrogen isotope analyses of eggs. Revista Brasileira de Ciência Avícola/ Brazilian Journal of Poultry Science 2008;10(3):147-152

Deniro MJ, Epstein S.You are what you eat (plus a few \%o) the carbon isotope cycle in food chains [abstract]. Geological Society of America 1976;6:834.

Deniro MJ, Epstein S. Influence of diet on the distribution of carbon isotopes in animals. Geochimica et Cosmichimica Acta 1978;42(5):495-506.
Deniro MJ, Epstein S. Influence of diet on the distribution of nitrogen isotopes in animals. Geochimica et Cosmichimica Acta 1981; 45(3):341-351.

González-Martin I, González-Pérez C, Hernández-Méndez J, Sánchez González C. Differentiation of dietary regimen of Iberian swine by means of isotope analysis of carbon and sulphur in hepatic tissue. Meat Science 2001;58(1):25-30.

González-Martin I, González-Pérez C, Hernández Méndez J, MarquésMacias E, Sanz Poveda F. Use of isotope analysis to characterize meat from Iberian-breed swine. Meat Science 1999;52(4):437-441.

Handley LL, Raven JA. The use of natural abundance of nitrogen isotopes in plant physiology and ecology. Plant Cell and Environment 1992;15(9):965-985.

Móri C, Garcia EA, Ducatti C, Denadai JC, Gottmann R, Mituo MAO. Poultry offal meal traceability in meat quail tissues using the technique of stable carbon $\left({ }^{13} \mathrm{C} /{ }^{12} \mathrm{C}\right)$ and nitrogen $\left({ }^{15} \mathrm{~N} /{ }^{14} \mathrm{~N}\right)$ isotopes. Revista Brasileira de Ciência Avícola/ Brazilian Journal of Poultry Science 2008;10(1):45-52,

Móri C, Garcia EA, Ducatti C, Denadai JC, Pelíca K, Gottmann R, Mituo $\mathrm{MAO}$, Bordinhon AM. Traceability of animal byproducts in quail (Coturnix coturnix japonica) tissues using carbon $\left({ }^{13} \mathrm{C} /{ }^{12} \mathrm{C}\right.$ ) and nitrogen $\left({ }^{15} \mathrm{~N} /{ }^{14} \mathrm{~N}\right)$ stable isotopes. Revista Brasileira de Ciência Avícola/ Brazilian Journal of Poultry Science 2007;9(4):263-269.

Oliveira RP, Ducatti C, Pezzato AC, Denadai JC, Cruz VC, Sartori JR, Carrijo AS, Caldara F. Traceability of poultry offal meal in broiler feeding using isotope analysis $\left(\delta^{13} \mathrm{C}\right.$ and $\left.\delta^{15} \mathrm{~N}\right)$ of different tissues. Revista Brasileira de Ciência Avícola/ Brazilian Journal of Poultry Science 2010; 12(1):13-20.

Piasentier E, Valusso R, Camin F, Versini G. Stable isotope ratio analysis for authentication of lamb meat. Meat Science 2003;64(3):239-247.

Rosa CR, Moraes M, Neto JAG, Nobrega JA, Nogueira AR. Effect of modifiers on thermal behavior of Se in acid digestates and slurry of vegetables by graphite furnace atomic absorption spectrometry. Food Chemistry 2002;79:517-523

Rostagno HS, Albino LFT, Donzele JL, Gomes PC, Ferreira AS, Oliveira RF, Lopes DC. Tabelas brasileiras para aves e suínos: Composição de alimentos e exigências nutricionais. Viçosa (MG): UFV; 2005.

SAS Institute. SAS/STATTM. SAS user's guide for windows environment. 8.0 ed. Cary (NC); 1999.

Shibuya EK, Sarkis JE S, Neto ON, Moreira MZ, Victoria RL. Souring Brazilian marijuana by applying IRMS analysis to seized samples. Forensic Science International 2006;160(1):35-43.

Tieszen LL, Boutton TW, Tesdahl KG, Slade NA. Fractionation and turnover of stable carbon isotopes in animal tissues: implications for $\delta^{13} \mathrm{C}$ analysis of diet. Oecologia 1983;57(1-2):32-37

Vogel JC. Variability of carbon isotope fractionation during photosynthesis. In: Ehleringer JR, Hall AE, Farquhar GD, editors. Stable isotopes and plant carbon-water relations. San Diego: Academic Press; 1993. p. 2946.

Werner RA, Schimidt HL. The in vivo nitrogen isotope discrimination among organic plant compounds. Phytochemistry 2002;61(5):465-484. 